\title{
PENGHAMBATAN OKSIDASI LIPIDA IKAN TUNA OLEH AIR JAHE SELAMA PENYIMPANAN DINGIN
}

\author{
(Inhibition of Tuna Lipid Oxidation by Ginger Extract during Refrigeration)
}

\author{
Silvana D. Harikedua ${ }^{1}$ \\ ${ }^{1}$ Fakultas Perikanan dan Ilmu Kelautan Universitas Sam Ratulangi, Manado, Sulawesi Utara
}

\begin{abstract}
The effects of ginger extract supplementation on lipid oxidation of raw tuna during refrigerated storage for 9 days were examined. Lipid oxidation was assessed by monitoring peroxide and malonaldehyde formation in raw tuna at $0,3,6$ and 9 days of refrigerated storage. Results showed that all ginger extracts treatments significantly increased the stability of frozen tuna to lipid oxidation compared with the control. Ginger extracts of $2 \%$ and $3 \%$ was more effective in inhibiting lipid oxidation of raw tuna than $1 \%$ extract.
\end{abstract}

Keywords: Tuna, ginger extract, antioxidant, refrigerate storage, peroxide, malonaldehyde.

Tujuan penelitian ini adalah untuk mengetahui efek suplementasi ekstrak air jahe pada oksidasi lipida daging ikan tuna yang disimpan selama 9 hari. Oksidasi lipida ikan tuna beku dievaluasi berdasarkan nilai bilangan peroksida dan pembentukan malonaldehyde (njlai TBA) pada hari ke 0, 3, 6 dan 9 penyimpanan. Hasil penelitian menunjukkan bahwa suplementasi-ekstrak air jahe meningkatkan stabilitas ikan tuna beku terhadap oksidasi lipida dibandingkan dengany kontrol. Ekstrak air jahe $2 \%$ dan $3 \%$ lebih efektif dalam menghambat oksidasi lipida daging ikan tura selama penyimpanan dibandingkan ekstrak air jahe $1 \%$.

Kata kunci: Tuna, ekstrak jahe, antioksidan, penyimpandn dingtin, peroksida, malonaldehid.

\section{PENDAHULUAN}

Ikan sangat rentan mengalami keman duran mutu secara mikrobiologi dan kimiak karena komposisi kimianya (Goulas \& Kontoninas, 2007). Salah satu yang banyak mendapat perhatian untuk diteliti adalah lipida ikan yang sangat sensitif terhadap oksidasi karena mengandung asam-asam lemak tidak jenth omega-3 dan omega-6. Asam-asam lemak tidak jenuh seperti asam eikosapentaenoat (EPA, 20: 5n-3) dan asam dokosaheksaenoat (DHA, 22:6n-3) dapat teroksidasi dengan mudah oleh berbagai katalisator seperti oksigen, panas, cahaya, keberadaan logam dat sebagainya. Asam-asam lemak pada ikan, yang rentan teroksidasi menghasilkan hidroperoksida dan hasil uraian lain seperti aldehit Keton dan alkohol yang dapat menyebabkah penurunan mutu ikan segar (Sohn et al. 2005).

Salah satu cara efektif untuk mencegah kerusakan oksidatif adalah dengan penggunaan antioksidan. Antioksidan adalah senyawa yang dapat menghambat oksidasi dengan cara menangkal reaksi radikal bebas (YanishlievaMaslarova, 2001). Antioksidan dapat juga memperpanjang umur simpan bahan pangan dengan cara melindungi bahan pangan terhadap proses deteriorisasi yang disebabkan oleh oksidasi seperti ketengikan, perubahan warna dan - hilangnya nilai nutrisi (Mikova, 2001).

Antioksidan dapat dibagi dalam dua kelompok berdasarkan sumbernya yaitu antioksidan sintetik dan antioksidan alami. Beberapa antioksidan sintetik yang paling umum digunakan adalah komponen fenolik seperti butylated hydroxyanisol (BHA), butylated hydroxytoluene (BHT), tertiary butylhydroquinone (TBHQ), dan ester dari asam galat contohnya propil galat (PG) (Yanishlieva-Maslarova, 2001). Senyawa antioksidan alami umumnya dapat ditemukan pada tumbuhan, mikroorganisme, fungi dan juga pada jaringan hewan. Senyawa antioksidan alami sebagian besar adalah senyawa fenolik dan grup yang paling penting dari senyawa antioksidan alami adalah tokoferol, flavonoid, tokoferol dan asam fenolik (Yanishlieva-Maslarova, 2001).

Salah satu contoh antioksidan alami adalah jahe. Jenis antioksidan fenolik pada jahe yang sudah dikenal adalah gingerol, shogaol, zingeron dan diarilheptanoid (Septiana et al. 2002). Selanjutnya El-Baroty et al. (2010) melaporkan bahwa ekstrak minyak jahe dikarakterisasi oleh konsentrasi tinggi senyawa hidrokarbon sekuisterpen seperti $\beta$-sesquiphellandrene 
$(27,16 \%)$, caryophyllene $(15,29 \%)$, zingiberene $(13,97 \%), \alpha$-farnesene $(10,52 \%)$ dan ar-curcumin $(6,62 \%)$. Hasil penelitian Septiana et al. (2002) menunjukkan bahwa ekstrak air jahe mengandung fenol sebesar $4,77 \mathrm{mg} / \mathrm{g}$, yang berarti memiliki antioksidan fenolik untuk dapat mencegah oksidasi lemak dan minyak. Ekstrak air jahe tersebut dapat menghambat pembentukan malonaldehid pada asam linoleat yang diinkubasi selama 16 hari.

Sehubungan dengan hal-hal tersebut, maka penelitian ini dirancang untuk melihat efek pemberian ekstrak air jahe (Zingiber officinale Roscoe) sebagai antioksidan terhadap oksidasi lipida ikan tuna khususnya ikan tuna madidihang (Thunnus albacores) selama penyimpanan dingin.

\section{METODE PENELITIAN}

Bahan baku sebagai sampel adalah ikan tuna madidihang segar, berukuran 2000-3000 gram (g). Setiap bagian daging ikan, daerah belakang kepala, perut dan ekor kemudian diambil sehingga berjumlah 2000 g untuk kemudian diberi perlakuan. Jahe Merah (Zingiber officinale Rosc. var rubrum) segar sebanyak $750 \mathrm{~g}$ digunakan untuk mendapatkan air jahe \pm 250 $\mathrm{ml}$. Jahe segar dicuci dengan air bersih, dikupas/dikerok bagian luarnya, dipotong menjadi bagian yang lebih kecil, kemudian dimasukkan ke dalam pengejus untuk mendapatkan air jahe.

Perlakuan penambahan ekstra air jahe yang diterapkan dalam penelitian ini terdiri atas 4 jenis sebagai berikut yaitun $\mathrm{A}_{2}$ kontrol tanpa penambahan), $A_{1}$ (sampel dengan penambahan $1 \%), \mathrm{A}_{2}$ (sampel dengan penambahan $2 \%$ ), $\mathrm{A}_{3}$ (sampel dengan penâmbahan 3\%). Seluruh sampel disimpan pada $s a b u+5^{\circ} \mathrm{C}$ dan pengamatan dilakukan pada $0,3,6$, dan 9 hari penyimpanan. Untuk mengemas ikan digunakan bahan pengemas plastik PE (polietilen). Alat ekstraksi soxhlet erlenmeyer, timbangan dan oven dipakai untuk mengeringkan sampel.

\section{Penentuan Bilangan Peroksida}

(SNI 01-2347-1991)

Sebanyak \pm 1 g minyak ditimbang ke dalam erlenmeyer bertutup kasa, ditambahkan 50 $\mathrm{ml}$ pelarut campuran (kloroform dan asam asetat glasial) dikocok kuat-kuat, lalu ditambahkan $1 \mathrm{~g}$ kristal KI jenuh dan diletakkan di tempat gelap selama 30 menit. Setelah itu ditambahkan $50 \mathrm{ml}$ akuades, $5 \mathrm{ml}$ indikator amilum kemudi- an dititrasi dengan $0,002 \mathrm{~N}$ larutan Natrium Thiosulfat $\left(\mathrm{Na}_{2} \mathrm{~S}_{2} \mathrm{O}_{3}\right)$, lalu dibuat blanko lain dengan cara yang sama. Bilangan peroksida dihitung berdasarkan sejumlah Iod yang dibebaskan dari Kalium Iodida melalui reaksi oksidasi oleh peroksida dalam lemak/minyak pada suhu ruang di dalam medium asam asetat/kloroform.

\section{Penentuan Angka TBA}

(Apriyantono et al., 1989)

Sebanyak $10 \mathrm{~g}$ sampel, dimasukkan ke pelumat, ditambahkan $50 \mathrm{ml}$ akuades dan dihancurkan selama 2 menit. Sampel dipindłák secara kuantitatif ke dalam labu distilasi sambil dicuci dengan akuades dan difambahkan $\pm 2,5$ $\mathrm{ml} \mathrm{HCl} \mathrm{4M} \mathrm{sampai} \mathrm{pH}$ menjadi 155. Selanjutnya larutan didistilasi dengan 10 menit pemanasan tinggi sehingga dipereleh $50 \mathrm{ml}$ destilat. Ambil $5 \mathrm{ml}$ larutan destilat ke dalam tabung reaksi bertutup, lalu ditambahkan $5 \mathrm{ml}$ pereaksi TBA dan dipanaskan selama 35 menit dalam air mendidih. Dibuat blanko dengan mengunakan $5 \mathrm{ml}$ akuades dan $5 \mathrm{ml}$ pereaksi. Tabung reaksi didinginkan dengan air dingin selama \pm 10 menit, kemudian diukur absorbansinya (D) pada panjang gelombang $528 \mathrm{~nm}$ dengan larutan blanko Sebagai titik nol. Digunakan sampel sel berdiameter $1 \mathrm{~cm}$. Dihitung bilangan TBA, dinyatakan dalam mg malonaldehid per kg sampel.

\section{HASIL DAN PEMBAHASAN}

\section{Bilangan Peroksida}

Pengukuran nilai bilangan peroksida dilakukan untuk mengetahui hasil oksidasi primer lipida ikan tuna. Tabel 1 menunjukkan bahwa rerata bilangan peroksida ikan tuna yang diberi perlakuan penyimpanan dingin (3, 6 dan 9 hari) lebih tinggi dibandingkan dengan ikan tuna tanpa penyimpanan, sedangkan rerata bilangan peroksida ikan tuna yang diberi air jahe $(1 \%, 2 \%$, dan 3\%) lebih rendah dibandingkan dengan bilangan peroksida ikan tuna tanpa air jahe. Bilangan peroksida tertinggi adalah $7,06 \mathrm{meq} /$ $1000 \mathrm{~g}$ contoh yaitu pada ikan yang disimpan selama 6 hari tanpa penambahan air jahe, sedangkan terendah yaitu $1,76 \mathrm{meq} / 1000 \mathrm{~g}$ contoh pada interaksi perlakuan pemberian air jahe 3\% dan tidak mengalami perlakuan penyimpanan $(0$ hari).

Hasil uji beda Duncan (DMRT) menunjukkan perbedaan sangat nyata antara sampel yang tidak diberi air jahe dengan sampel yang diberi air jahe $1 \%, 2 \%$ dan $3 \%$. Hal ini menun- 
jukkan bahwa pemberian air jahe 1\%,2\% dan $3 \%$ sebagai antioksidan pada ikan tuna dapat menghambat proses oksidasi lipida dalam hal ini menekan kenaikan bilangan peroksida. Hasil penelitian menunjukkan bahwa semakin tinggi konsentrasi air jahe yang diberikan, semakin menurun peroksida yang terbentuk. Hal ini diduga disebabkan oleh aktivitas antioksidan yang terkandung dalam air jahe terutama senyawa fenolik sehingga laju oksidasi dapat ditekan.

Tabel 1. Bilangan Peroksida Ikan Tuna Segar yang Diberi Variasi Konsentrasi Air Jahe selama Penyimpanan Dingin $\left(5^{\circ} \mathrm{C}\right)$

\begin{tabular}{ccccc}
\hline \multirow{2}{*}{$\begin{array}{c}\text { Konsentrasi } \\
\text { Air Jahe }\end{array}$} & \multicolumn{4}{c}{$\begin{array}{c}\text { Bilangan Peroksida (meq/1000g contoh) } \\
\text { Selama Penyimpanan Dingin (hari) }\end{array}$} \\
\cline { 2 - 5 } & 0 & 3 & 6 & 9 \\
\hline $0 \%$ & $3,30^{\mathrm{a}, \mathrm{x}}$ & $5,78^{\mathrm{a}, \mathrm{y}}$ & $7,06^{\mathrm{a}, \mathrm{y}}$ & $5,99^{\mathrm{a}, \mathrm{y}}$ \\
$1 \%$ & $3.03^{\mathrm{b}, \mathrm{x}}$ & $4,57^{\mathrm{b}, \mathrm{y}}$ & $5,20^{\mathrm{b}, \mathrm{y}}$ & $4,96^{\mathrm{b}, \mathrm{y}}$ \\
$2 \%$ & $2,73^{\mathrm{bcx}}$ & $3,70^{\mathrm{bc}, \mathrm{y}}$ & $4,33^{\mathrm{bc}, \mathrm{y}}$ & $4,13^{\mathrm{bc}, \mathrm{y}}$ \\
$3 \%$ & $1,76^{\text {,cx }}$ & $3,34^{\mathrm{c}, \mathrm{y}}$ & $3,58^{\mathrm{c}, \mathrm{y}}$ & $3,43^{\mathrm{c}, \mathrm{y}}$ \\
\hline Ket.: Notasi huruf berbeda dalam 1 & kolom (a-c) & dan notasi \\
huruf berbeda dalam 1 baris (x-y) menyatakan perbedaan \\
nyata $(\mathrm{P}<0,05)$ (DMRT).
\end{tabular}

Peran oksidatif air jahe ini mungkin serupa dengan kemampuan antioksidan $\alpha$-tokoferol yang beraksi sebagai pengait radikal peroksil (ROO*) dan merupakan pengait yang kuat terhadap radikal hidroksil $\left(\mathrm{OH}^{*}\right)$. Mekanisme radikal hidroksil $\left(\mathrm{OH}^{*}\right)$ dan radikal peroksil (ROO*) dengan antioksidan jahe dapat diasurm, sikan bahwa senyawa $\mathrm{OH}^{*}$ yang tertangkap antioksidan pada jahe $\left(\mathrm{AH}_{2}\right)$ akan diregenerasi menjadi $\mathrm{H}_{2} \mathrm{O}$ dan $\mathrm{ROO}^{*}$, serta $\mathrm{AH}_{2}$ diregenerasi menjadi ROOH (Septiana et al., 2002).

Gambar 1 menunjukkaptbahwa nilai bilangan peroksida ikan tuna disimpan 3, 6, dan 9 hari lebih tinggi jika clibandingkan dengan perlakuan penyimpanan 0 hari. Hal ini dapat terjadi karena pada penyimpanan 0 hari oksidasi baru mulai bertangsung dan diasumsikan peroksida yang terbentuk masih sedikit. Bilangan peroksida cenderung meningkat selama 0-6 hari dan kemudian mengalami penurunan pada hari ke-9. Hal ini diduga terjadi karena selama $0-6$ hari terbentuk peroksida-peroksida pada tahap propagasi sedangkan pada penyimpanan 9 hari telah terjadi dekomposisi hidroperoksida yang antara lain membentuk malondialdehid sebagai hasil oksidasi sekunder.

Penurunan signifikan nilai peroksida setelah mencapai nilai maksimum menunjukkan bahwa peroksida adalah komponen yang kurang stabil dan sangat rentan untuk mengalami perubahan lanjutan yang menghasilkan produk oksidasi sekunder (Marzena dan Miroslawa, 2005).
Produk degradasi lanjutan yang dihasilkan oleh proses oksidasi asam lemak tak jenuh adalah komponen volatil berberat molekul rendah seperti aldehid, keton, alkohol, hidrokarbon dan polimer lainnya (Misharina dan Polskov, 2005; Boyd et al., 1983),

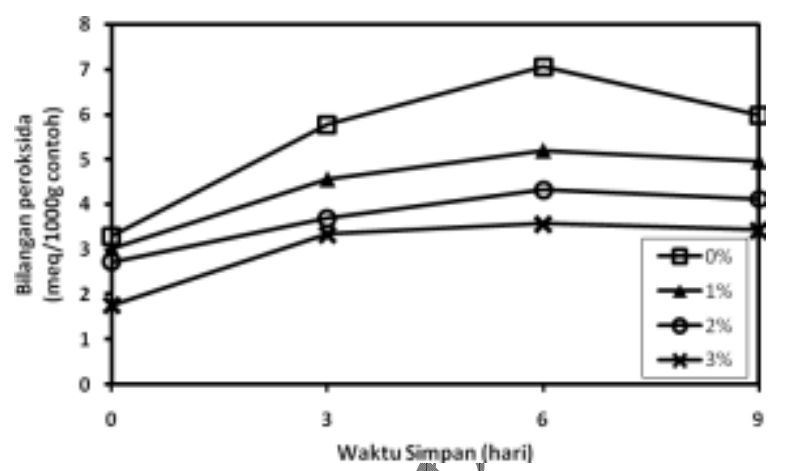

Gambar 1. Bilangan Pecolda Jkan Tuna Segar yang Diberi Vałasi Konsentrasi Air Jahe dan Disimpan Dingin Selama 9 hari.

Bilangańperoksida tertinggi adalah 7,06 meq/1000 g contoh ditemukan pada ikan yang disimpan selama 6 hari $(0 \%$ air jahe). Nilai peroksida tertinggi yang masih dapat ditoleransi adalah ro-20 meq/1000 g (Huss, 1995). Hidroperoksida (produk awal oksidasi) adalah intermediat yang tidak berbau tetapi jika dipecah menjadi molekul yang lebih kecil akan membentuk bau lumpur/off-flavor (Hamilton, 1994). Produk hasil reaksi oksidatif akan mempengaruhi karakteristik organoleptik seperti aroma dan rasa sehingga tidak layak dikonsumsi (Romtamzad et al., 2011). Hal ini menunjukkan bahwa ikan tuna yang diberi jahe masih dapat dikonsumsi konsumen sampai pada hari ke-9 penyimpanan dan tidak menyebabkan perubahan pada aroma dan rasa ikan itu sendiri.

\section{Angka Asam Tiobarbiturat (TBA)}

Tabel 2 menunjukkan angka TBA tertinggi yaitu $2,95 \mathrm{mg} \mathrm{MA} / \mathrm{kg}$ contoh pada ikan tuna yang tidak diberi air jahe dan disimpan dingin selama 9 hari, sedangkan nilai terendahnya adalah $0,45 \mathrm{mg} \mathrm{MA} / \mathrm{kg}$ contoh yaitu pada ikan tuna yang diberi air jahe 3\% dan tidak mengalami perlakuan penyimpanan dingin. Hal yang sama diteliti oleh Zakipour dan Divband (2012) juga menunjukkan bahwa ikan mas yang disimpan pada suhu $4^{\circ} \mathrm{C}$ dan ditambahkan dengan antioksidan minyak atsiri $Z$. multiflora Boiss masih memiliki nilai TBA antara $0,52-0,75 \mathrm{mg}$ $\mathrm{MA} / \mathrm{kg}$ hingga hati ke-15.

Hasil uji beda Duncan (DMRT) pengaruh konsentrasi air jahe terhadap nilai TBA me- 
nunjukkan bahwa perlakuan konsentrasi $2 \%$ dan $3 \%$ memberi pengaruh berbeda sangat nyata terhadap perlakuan $1 \%$ dan $0 \%$. Rata-rata angka TBA tertinggi adalah $2,41 \mathrm{mg} \mathrm{MA} / \mathrm{kg}$ contoh pada ikan tanpa air jahe sedangkan rata-rata angka TBA terendah adalah 1,46 mg MA $/ \mathrm{kg}$ contoh pada ikan dengan konsentrasi air jahe $3 \%$. Hal ini bisa disebabkan karena perlakuan pemberian konsentrasi air jahe $2 \%$ dan $3 \%$ memberi efek maksimal sebagai antioksidan dibanding dengan air jahe konsentrasi $1 \%$.

Tabel 2. Angka Asam Tiobarbiturat (TBA) Ikan Tuna Segar yang Diberi Variasi Konsentrasi Air Jahe Selama Penyimpanan Di$\operatorname{ngin}\left(5^{\circ} \mathrm{C}\right)$

\begin{tabular}{ccccc}
\hline \multirow{2}{*}{$\begin{array}{c}\text { Konsentrasi } \\
\text { Air Jahe }\end{array}$} & \multicolumn{4}{c}{$\begin{array}{c}\text { Angka TBA (mg MA/kg contoh) } \\
\text { Selama Penyimpanan Dingin (hari) }\end{array}$} \\
\cline { 2 - 5 } & 0 & 3 & 6 & 9 \\
\hline $0 \%$ & $1,76^{\mathrm{a}, \mathrm{x}}$ & $2,28^{\mathrm{a}, \mathrm{y}}$ & $2,65^{\mathrm{a}, \mathrm{yz}}$ & $2,95^{\mathrm{az}}$ \\
$1 \%$ & $1,81^{\mathrm{a}, \mathrm{x}}$ & $2,15^{\mathrm{a}, \mathrm{y}}$ & $2,22^{\mathrm{a}, \mathrm{yz}}$ & $2,89^{\mathrm{a}, \mathrm{z}}$ \\
$2 \%$ & $0,98^{\mathrm{b}, \mathrm{x}}$ & $1,81^{\mathrm{b}, \mathrm{y}}$ & $2,07^{\mathrm{b}, \mathrm{yz}}$ & $2,20^{\mathrm{b}, \mathrm{z}}$ \\
$3 \%$ & $0,45^{\mathrm{b}, \mathrm{x}}$ & $1,44^{\mathrm{b}, \mathrm{y}}$ & $1,89^{\mathrm{b}, \mathrm{yz}}$ & $2,11^{\mathrm{b}, \mathrm{z}}$ \\
\hline Ket.: Notasi huruf berbeda dalam 1 kolom (a-b) & dan notasi \\
huruf berbeda dalam 1 baris (x-z) menyatakan perbedaan \\
nyata $(\mathrm{P}<0,05)$. (DMRT)
\end{tabular}

Hasil penelitian juga menunjukkan bahwa angka TBA menurun seiring dengan meningkatnya konsentrasi air jahe yang diberikan pada ikan. Hal ini dapat disebabkan karena senyawa antioksidan dengan konsentrasi $3 \%$ me - $_{-}$ miliki penetrasi ke dalam daging ikan lebih besar dari $2 \%, 1 \%$ dan $0 \%$. Ini berarti daya terhadap radikal bebas dari lemak ikanjuga lebih besar pada konsentrasi yang febih tinggi. Mekanisme ini dapat dijelaskan melalui aktivitas antioksidan alami yang tondapat dalam jahe, yaitu adanya senyawa-seny y turunan fenol seperti gingerol, shogao1, zingeron, diarilheptanoid serta turunannya yang mampu bertindak sebagai antioksidan primer terhadap radikal lipid (Zakaria et at 2000). Eleazu dan Eleazu (2012) pada peneritian terhadap 6 varietas baru jahe di Nigeria bahwa jahe memiliki total kandungan fenol tinggi dan memiliki kemampuan sebagai antioksidan yang tinggi, terlihat pada kerpampuannya menangkal radikal 2,2-difenil1-pikrilhidrasil (DPPH). Mekanisme reaksi antioksidatif senyawa fenolik jahe terhadap daging ikan diduga dapat terjadi melalui pemberian atom hidrogen dari gugus hidroksil dengan cepat kepada radikal substratnya (Zakaria et al., 2000).

Gambar 2 menunjukkan bahwa terjadi peningkatan angka TBA selama penyimpanan dingin 3, 6 dan 9 hari. Hal ini berarti bahwa ter- jadi kenaikan jumlah penguraian hasil oksidasi lipida seiring dengan makin lamanya penyimpanan disebabkan karena peroksida-peroksida sebagai hasil oksidasi primer terurai lebih lanjut menjadi aldehid, keton dan alkohol.

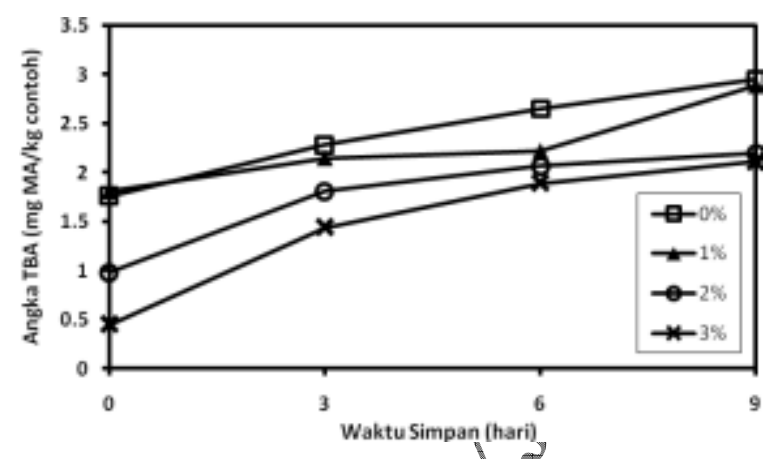

Gambar 2. Angka TBA Ikan Tuna Segar yang Diberi Variasi Konsentrasi Air Jahe dan Disimpan Ding Syama 9 hari.

Nilai TBA adalah salah satu indeks untuk menentukany derajat oksidasi lipida yang dihitung berdasarkan jumlah malondialdehid (MDA) dalam daging (Fernandez et al., 1997; Sallam, 2007). Malondialdehid dibentuk melalui-hidroperoksida yang merupakan produk awa1 hasil reaksi asam lemak tidak jenuh rantai panjang dengan oksigen (Fernandez et al., 1997). Malondialdehide (MDA) juga adalah produk toksin yang paling banyak diteliti sebagai produk reaksi lanjutan dari peroksidasi asam lemak tidak jenuh rantai panjang. (DelRio et al., 2005). Beberapa hasil penelitian memperlihatkan bahwa MDA dapat menginduksi tekanan oksidatif intraselular yang bisa melukai membran eritrosit (Tesoriere et al., 2002). MDA dapat bersifat genotoksik karena bereaksi dengan DNA membentuk sel mutagen pada sel tubuh manusia (Cline et al., 2004; Del-Rio et al., 2005; Riggins dan Marnett, 2001). Hasil penelitian biokimia lain juga menunjukkan bahwa konsumsi produk peroksidasi lipida meningkatkan frekuensi adanya tumor dan atherosklerosis (Esterbauer, 1993). Oleh karena itu, konsumsi makanan yang tercemar dengan MDA dapat menimbulkan risiko kesehatan yang serius.

Nilai maksimum TBA yang masih mengindikasikan kualitas baik dari daging ikan adalah $5 \mathrm{mg}$ MA/kg (Sallam, 2007). Daging ikan tuna tanpa diberi air jahe dan disimpan dingin $\left(5^{\circ} \mathrm{C}\right)$ sampai pada hari ke-9 memiliki nilai angka TBA tertinggi 2,95 $\mathrm{mg} \mathrm{MA} / \mathrm{kg}$ contoh, sedangkan nilai angka TBA daging ikan tuna yang diberi air jahe $1-3 \%$ berkisar 2,11-2,89 $\mathrm{mg} \mathrm{MA} / \mathrm{kg}$ contoh. Hal ini menunjukkan bahwa 
daging ikan yang disimpan dingin sampai pada hari ke-9 masih aman dikonsumsi.

Hasil uji statistika menunjukkan tidak adanya perbedaan nyata nilai TBA antara daging ikan tuna yang diberi penambahan air jahe $1 \%$ dan tanpa penambahan air jahe sampai penyimpanan pada hari ke-9. Hal ini menunjukkan bahwa ekstrak air jahe menghambat oksidasi lipida sampai pada hari ke-6 penyimpanan.

\section{KESIMPULAN}

Konsentrasi ekstrak air jahe 2\% dan 3\% lebih efektif menghambat oksidasi lipida dibanding dengan konsentrasi ekstrak 1\%. Penambahan ekstrak air jahe sebagai antioksidan efektif menghambat oksidasi lipida hingga hari ke-6 penyimpanan.

\section{DAFTAR PUSTAKA}

[BSN]. Badan Standarisasi Nasional. 1991. SNI 01-23471991. Penentuan Bilangan Peroksida. BSN Indonesia.

Apriyantono A, Fardiaz D, Budiyanto S, Sedarnawati Y. 1989. Petunjuk Prosedur Analisis Pangan. PAU Pangan dan Gizi. Bogor. Institut Pertanian Bogor.

Boyd LC, Green DP, Gresbrecht FB, King MF. 1993. Inhibition of Oxidative Rancidity in Frozen Cooked Fish Flakes by tert-butyl Hydroquinone and Rosemary Extract. Journal of Science Food and Agriculture 61: 87-93.

Cline SD, Riggins JN, Tornaletti S, Marnett LJ, Hana walt PC. 2004. Malondialdehyde Adducts in DNA Arrest Transcription by T7 RNA Polymerase and Mammalian RNA Polymerase II. Proc. Natl. Acád. Sci. 101: 7275-7280.

Del-Rio D, Stewart AJ, Pellegrini N. 2005. A Review of Recent Studies on Malondialdehyde as Toxic Molecule and Biological Marken of Oxidative Stress. Nutr. Metabolism Cardiovascular Dis. 15: 316-328.

El-Baroty GS, Abd El-Baky HH, Farag RS, Saleh MA. 2010. Characterization of Antioxidant and Antimicrobial Compounds of Qinnamon and Ginger Essential Oils. African J of Brochemistry Research Vol. 4(6): $167-174$

Eleazu CO, Eleazu KC. 2012. Physico-chemical Properties and Antioxidant Potentials of $6 \mathrm{New}$ Varieties of Ginger (Zingiber officinale). American Journal of Food Technology 7(4): 214-221.

Esterbduer, H. 1993. Cytotoxicity and Genotoxicity of Lipid Oxidation Products. Am. J. Clin. Nutr. 57: 77957855 .

Fernandez J, Perez-Alvarez JA, Fernandez-Lopez JA. 1997. Thiobarbituric Acid Test for Monitoring Lipid Oxidation in Meat. Food Chemistry 59(3): 345-353.

Goulas AE, Kontominas MG. 2007. Combined Effect of Light Salting, Modified Atmosphere Packaging and Oregano Essential Oil on the Shelf-life of Sea Bream (Sparus aurata): Biochemical and Sensory Attributes. Food Chemistry 100: 287-296.
Hamilton RJ. 1994. The Chemistry of Rancidity in Foods. In JC. Allen and RJ. Hamilton (ed). Rancidity in foods. Glasgow: Chapman and Hall. pp. 1-21.

Huss HH. 1995. Quality and Quality Changes in Freshfish. FAO Fisheries Technical Paper No. 348, Food and Agriculture Organization (FAO) of the United Nations, Rome, Italy.

Marzena DO, Miroslawa T. 2005. Quality Changes in Selected Frying Fats during Heating in a Model System. Journal of Food Lipids 12: 159-168.

Mikova K. 2001. The Regulations of Antioxidant in Food. In: Pokorny J, N. Yanishlieva \& M. Gordon (ed). Antioxidants in Food. Boca Raton. CRC Press. Woodhead Publishing. pp. 267-284

Misharina, TA, Polshkov, AN. 2005. Antioxidant Properties of Essential Oils: Autoxidation of Essential Oils from Laurel and Fennel and of Their Mixtures with Essential Oil from Coriander.' Applied Biochemistry and Microbiology. 41(6): 610-618.

Riggins JN, Marnett LJ. 2001. Mutagenicity of The Malondialdehyde Oligomerization Products 2-(3-oxo-1 propenyl)-malondialdehyde and 2, 4-dihydroxymethylene-3-(2,2-dimethóxyethly) Glutaraldelyde in Salmonella. Mut. Res, 497:153-157.

Rostamzad H, Shabanpour B, Shabani A, Shahiri H. 2011. Enhancement of the storage quality of frozen Persian sturgeon fillets by using of ascorbic acid. International Food Research Journal 18: 109-116

Sallan IK. 2007 Antimicrobial and Antioxidant Effects of - Sodurum Acetate, Sodium Lactate, and Sodium Citrate in Refrigerated Sliced Salmon. Food Control. 18(5): 566-575.

- Septiana AT, Muchtadi D, Zakaria FR. 2002. Aktivitas Antioksidan dari Ekstrak Diklorometana dan Air Jahe (Zingiber officinale Roscoe) pada Asam Linoleat. J. Teknologi dan Industri Pangan. 13 (2).

Sohn HH, Taki Y, Ushio H, Kohata T, Shioya I, Ohshima T. 2005. Lipid Oxidations in Ordinary and Dark Muscles of Fish: Influences on Rancid Off-odor Development and Color Darkening of Yellowtail Flesh During Ice Storage. J Food Science 70(7): S490-S496.

Tesoriere L, D'Arpa D, Butera D, Pintaudi AM, Allegra M, Livrea MA. 2002. Exposure to Malondiadehyde Induces an Early Redox Unbalance Preceding Membrane Toxicity in Human Erthrocytes. Free-Radi: cRes. 36: 89-97.

Yanishlieva-Maslarova NV. 2001. Inhibiting Antioxidant. In: Pokorny J, Yanishlieva N, Gordon M (ed). Antioxidants in Food. Boca Raton. CRC Press. Woodhead Publishing. pp. 22-70

Zakaria F, Susanto H, Hartoyo A. 2000. Pengaruh Konsumsi Jahe (Zingiber officinale Roscoe) Terhadap Kadar Malonaldehida dan Vitamin E Plasma pada Mahasiswa Pesantren Ulil Albaab Kedung Badak Bogor. Buletin Teknologi dan Industri Pangan 11 (1).

Zakipour RE, Divband M. 2012. The Effects of Coating and Zataria multiflora Boiss Essential Oil on Chemical Attributes of Silver Carp Fillet Stored at $4^{\circ} \mathrm{C}$. International Food Research Journal 19(2): 685690. 